\title{
Gender Differences in Academic Performance and Industry Relevance: a Study of a Nigerian Private University Graduates
}

\author{
TAYO O. GEORGE \\ Department of Sociology, Covenant University, NIGERIA \\ MOFOLUWAKE P. AJAYI \\ Department of Sociology, Covenant University, NIGERIA \\ OLAWALE Y. OLONADE \\ ${ }^{1}$ Department of Sociology, Covenant University, NIGERIA \\ ${ }^{2}$ Centre for Economic Policy and Development Research, Covenant University, NIGERIA \\ TEMILORUN OLANIPEKUN \\ Department of African Studies, Oxford University, United KINGDOM \\ MERCY E. ADEBAYO \\ Department of Sociology, Covenant University, NIGERIA
}

\begin{abstract}
This article examines the linkage between university education, academic performance, and industry relevance among graduates of a Nigerian Private University in Ogun State, Southwest, Nigeria. Multiple research methods, including existing records from secondary sources and In-depth interviews, were used for the primary data collection. Existing record on students' academic performance obtained from the University's Center for Systems and Information (CSIS) for all academic programs in the two colleges sampled: College of Development Studies (CDS) and College of Science and Technology (CST) in the University was complemented by In-depth interviews of academic advisers and heads of department across the programs in addition to the data from the University's Alumni office on present places of employment of the graduates within the stipulated period (2006-2018). The study found that the female graduates' excellent academic performance across various programs did not reflect in industry relevance in terms of visibility in the economy's critical formal sectors compared to their male counterparts. The study recommends the need for female graduates' urgent pragmatic steps to maximize the benefits of career opportunities by translating the same into paid employment.
\end{abstract}

Keywords: Gender, Academic performance, Industry Relevance, University

Received: July 26, 2020. Revised: February 5, 2021. Accepted: February 18, 2021.

Published: February 26, 2021.

\section{Introduction}

Essentially, as obtainable across the globe, Gender classification characterized Nigerian society. In other words, based on the sex of their citizens, men and women receive unequal access to power, prestige, and property. $[1 ; 2]$. Gender is a social construct that denotes social and economic privileges attached to being male or female [3]. For any nation to maintain overall development, its socio-economic factors and groups would have to harness their developmental efforts and achievements [4]. It has been observed that gender differences affect the development and practice of all sectors [5]. Gender differences in the occupation are 
arguably the basis of division of labor. Even in traditional societies - hunting and gathering societies - there are men's jobs and women's jobs. In all aspects of human interaction, traditional and cultural beliefs have always been maintained to the womenfolk's detriment $[6,7]$. Hence, this paper focuses on gender differences in Covenant University graduates' academic performance to ascertain the attendant implications for industry relevance among covenant university graduates between 20062012 when the University released her set of graduates referred to as ${ }^{6}$ eagles.

It is observed that the divergent reality of educational attainment and industry relevance has a lot to do with gender differences. Female students do better than their male counterparts in schools. On the other hand, male graduates are more prominent, daring, risk-takers, and enterprising in the labor market. It is observed that female students could be more or less theoretical than practical in their approach, which affects their chances for employment. Also, female students are more concerned with their academic grades than their male counterparts. Females' superior performance above males in higher education appears to be a growing global occurrence [8]. Female students perform better than male students academically [9]. However, in the labor market, male graduates utilize their potential than their female counterparts.

Moreover, in South-eastern Nigeria, it was reported by (UBEC 2003) that an increasing number of boys are out of school compared to girls. This condition is a result of specific influences distracting the boys out of school. These influences manifest in their choice to go into business, long educational process, parental influences, lack of jobs, and low or no counsel. Male students may not do well in academics but excel in the labor market. This paper aims to determine the differences between male and female academic performance, that is, class of degree, and to find out where they are presently engaged in the industry. Other specific objectives include determining the differences between the male and female classes of degree between 2006 to 2018 . To find out whether the class of degree obtained has any influence on industry relevance.

\section{Problem Formulation}

\subsection{The Concept of Gender}

Whenever gender issues are discussed, various misunderstandings make many individuals start thinking of battle or war that either the male or the female must fight and win. All that is required is to give women equal opportunities in society as they are offered to men. Gender and growth are intended to ensure that both women and men profit from transition [10]. Not only does gender apply to individual identity and personality, but it can also be studied at the symbolic and systemic level.

Symbolic Level: It refers to the cultural concepts of masculinity and femininity and their stereotypes. From culture to culture, gender ideas and roles differ. The socialization mechanisms in childrearing, schooling, youth culture, working practices, and family ideology transform baby boys and girls into adult men and women [7].

Structural Level: The sexual division of labor in companies and institutions. The presence of unequal specialization or allocation of a task in the home, including amongst men and women whom both have outside full-time jobs, and discrimination in employment, where sex (rather than the skills and qualifications of individuals) plays a significant role in deciding work types and prospects for promotion (Oxford Dictionary of Sociology, 2004).

Notably, "gender concerns" are not the same as "the issues of women." Instead, understanding 'gender' means understanding opportunities, weaknesses, and the effects of change when influencing both women and men. Clearly, in an ever-changing world, cooperation and equality between women and men are the foundation for healthy families and viable nations [11]. The table below shows the marginalization and underrepresentation of women in the economy. 
Table 1: Gender Equality: Global Representation

\begin{tabular}{|l|l|l|}
\hline Section & Men & Women \\
\hline $\begin{array}{l}\text { World's Cabinet } \\
\text { Minister }\end{array}$ & $92 \%$ & $8 \%$ \\
\hline $\begin{array}{l}\text { World Media } \\
\text { Coverage }\end{array}$ & $83 \%$ & $17 \%$ \\
\hline $\begin{array}{l}\text { World's } \\
\text { Agriculture } \\
\text { Total Workforce }\end{array}$ & $49 \%$ & $51 \%$ \\
\hline $\begin{array}{l}\text { World's } \\
\text { Population of } \\
\text { Refugees and } \\
\text { Displaced }\end{array}$ & $20 \%$ & $80 \%$ \\
\hline
\end{tabular}

Source: (Ayodele, 2004)

From the above table, it is clear that women are underrepresented in the economy and political office compared to their male counterparts, with only $8 \%$ of women in the world's cabinet minister and a whopping $92 \%$ of men. Also, in the world media coverage, only $17 \%$ of women are represented while the rest are men. This may likely reduce the chances of women been heard through the media. However, a look at the statistics on agriculture, more women $(51 \%)$, shows the level of women subjugation in society. They are involved in the critical but unrecognized sector of the economy. Women also suffer from aftermath of wars, terrorism, and ethnic crises, thereby ending up as refugees and internally displaced camps such as we have them in the northern part of Nigeria.

\section{The Essence of University Education}

\subsection{Gender Differences in Educational Attainment}

Training is only one aspect of socialization in its broadest sense: it entails knowledge development and improved learning skills. Education also usually tends to form attitudes and right principles, whether deliberately or accidentally. According to Emile Durkheim, through education, necessary skills are imparted to persons for future endeavors. This assignment is specifically essential in industrial society with its complexities and specialization [12]. Importantly, education trains human resources for the economy. Education broadens women's experience then offers them opportunities to skills and resources, especially where they offer themselves for employment and use that opportunity to contribute to society's development [13].

Female educational attainment has been on a massive increase and remains one notable change in education in the last three decades. Recently in most advanced countries of the world, women and girls' educational attainment is far higher than that of men and boys. Among secondary school leavers, enrolment in tertiary education, and tertiary graduates, women have a higher number. Also, considering the current happenings, the gender gap in educational attainment may keep growing and favors women [12].

\subsection{Implication for Industrial Relevance}

Formal education serves as a precondition for employment in the economy's public and private sectors [14]. Traditionally, teaching has been seen as a female domain and an extension of mothering. While men tend to be more exploitative, women are likely to be more beneficial to all. Women have lower employment opportunities and labor force involvement rates than their male counterparts [15]. The female folk's biological makeup permits them to be gentle, caring, motherly and accommodating. By their nature, women can be declared natural managers, with a leadership style that is considered most appropriate for educational purposes [16].

On the other hand, many people believe that only men could perform specific jobs like mechanical, civil, electronic engineering, and computer/science/technology [17,13]. According to a study conducted by the Nigerian Universities Commission in 1997 on students' enrolment in universities from 1980-1992, females were less than $30 \%$ in basic sciences and science-based professional courses compared to arts-based courses [18]. Studies have consistently stated that mathematics and science are viewed as male domains [19].

Sociological research has shown that, in many respects, organizations are gendered [20]. Calling gendered organizations implies that gain 
and disadvantage, abuse and power, emotion and action, identity and sense are designed through and as related to distinguishing among male and female. However, companies and firms claim to maintain neutrality, but in a situation where the leadership position requirement often includes long working hours per day, executive meetings, weekend events, trips, and many outside work obligations. All these general working conditions automatically put women at a disadvantage due to responsibilities at home [1].

Therefore, according to [21], the workplace remains an essential ground for gender inequality in society due to the following reasons:

1. The workplace preserves sex separation by focusing and assigning diverse roles to women and men in different settings.

2. Gender differences in jobs results in uneven wages, control, and social status for men and women.

3. The expressions of inequality are subject to experiences at work.

The gender differences in responsibilities and roles in Nigeria often transform into inequity rather than complementarity. This also leads to an order in which women and men's roles and responsibilities are valued more than the other, and men subsequently get higher status than girls and women. This means that both female subordination and male superiority are determined by society.

More so, as a result of society's patriarchy, boys have more values than girls [7]. As a result of this, boys were socialized for public life achievement and provided more inspiration and preparation to meet life's possibilities. For females, socialization tends towards domestic activities like house chores, marital responsibilities, and childbearing. This patriarchy has also occasioned instances where men opposed women occupying leadership positions [4].

\subsection{Challenges Women Face in Industry}

The industrialization has promoted world development. However, in many African countries like Nigeria, the impact is still minimal [20]. Every year, about six million young men and women join the workforce, but only $10 \%$ can find jobs in the formal sector, and only onethird are women [23].

Women are seen more in the service sector than in the manufacturing sector. They play insignificant roles later because it requires more physical skills than mental skills [24]. According to [25], women are under-represented in occupations that require technical skills. This phenomenon is more marked at the lower technical skill level than at a professional technological level. In Nigeria, specialized occupations still represent a significant stronghold of gender stereotyping. While Nigerian women have generally registered a very marked increase in their recorded participation in economic activity, there remains a tendency for them to avoid technical occupations.

As a result, it is unusual to find women who work as production or repair personnel at the lower and middle technological levels. Production of stoves, ovens plates, pots, or the repair of leaking roofs, household utensils, shoes, or watches is regarded as belonging to the male occupational domain. Women who do such work are regarded as being outside of the culturally defined sphere of female work. Thus, they are considered masculine in their preference for occupation and, therefore, deviate from the regular pattern [25].

It is revealed that women in official occupations receive less pay compared to their male counterparts. The pay of men in all wage bands is consistently higher than that of women. A global problem that has persisted through political will and efforts is the gender wage gap. Comparably qualified women continue to gain less, doing equivalent work as men [26]. Irrespective of their educational qualifications, women receive lower wages compared to men. They earn less than men with lower qualifications in some situations. Women hold less than $30 \%$ of all public sector posts and just $17 \%$ of senior positions [24]. 
[27] noted that in some cases, women in formal employment might need to quit their jobs when they need to go for maternity. The world economic crisis and the gap between work growth and the rise in the number of unemployed graduates have exacerbated both women's and men's' conditions. However, due to their relative lack of training and education, the propensity to direct women into specific jobs, and the continuing heavy burdens of unpaid domestic work, childbearing, and childcare, women face more significant vulnerabilities in the labor market, which reduced their available energy and time for income-earning endeavors.

With an annual business volume of over US $\$ 42 \mathrm{~m}$, the extractive industry has almost zero participation levels. Regrettably, women lack access to the benefits of oil, gas, and mining resources either at the individual or community level. Only the men are mainly working in the extractive industries, leaving women with the cost of social disruption and environmental degradation in the oil community, which results in various explorations and mining activities [11, 23].

In economic terms, there is no country where women earn more than men [28]. Women are disadvantaged by their biology; menstruation, childbirth, and menopause are all physical pressures for women, but when women are pregnant or breastfeeding infants, pregnancy and breastfeeding have the most severe social implications, depending on males as breadwinners, whether husband, lover, brother and many more. Women's dependency on men is prolonged by the long duration during which human babies are dependent on their mothers compared to other animals' babies. This dependency on men is universal and established an unequal relationship of power [29].

Men became influential in the face of this dependency. Men go hunting, build houses, and meet other women's standards of survival. The role played by men was thus not only respected but also prestigious. In comparison, the ordinary routine was given little dignity and ideals, taken for granted by women's activities. The genesis of female minority status in society was characterized by this [30].

\subsection{Barriers to Formal Employment for Women}

Reproductive functions imply that women usually let go of advancement to higher-paying positions if these require anti-social hours or regular travel away from their families. In the circumstances like this, schooling on its own does not inherently boost prospects for better paying formal jobs [24]

According to [31], the low participation of females in science and technology-related sectors are attributable to the following;

i. Women have to put in extra effort to perform better than their male counterparts in similar positions.

ii. Women often suffer long delays in gaining promotion due to a combination of their productive and reproductive roles.

iii. Harassment from male counterparts. Sexual harassment is a barrier to equity in the workplace. Because sexual harassment is about power and control, many women victims feel unable to confront their harassers [32].

iv. Also important is the early marriages and other cultural factors that tend to truncate girls' education.

While the press gives the idea that women have endless possibilities and have made remarkable career strides, the workplace truth is far more discouraging. While women have made considerable strides in various ways, most women face gender differentiation in the workplace and debase their roles [32].

With time, resources, and expertise, women's jobs in home-housework, childcare, and parenting are highly challenging. Despite their growing involvement in the labor force, women still do the most at home. Housework is seen as demeaning and lacking in merit because it is synonymous with women. This is motherhood's price; the world's most valuable work is still the least respected [32]. 


\section{Problem Solution}

\subsection{Findings on Class of Degree and Industry Relevance}

Employers are looking for excellent academic achievement with the increasing number of graduates and fierce competition for jobs. The presentation of workplace skills such as teamwork, communication, and problem-solving skills are now essential criteria for improving employability and the industrial relevance of an individual, in addition to academic success or grade level. Both Government and students expect universities to prepare them more precisely than in the past for their future careers. Therefore, the industry's relevance is of critical importance to any leading university, and there is little doubt that it affects student hiring, retention, and satisfaction. These were captured as explained by current students when asked the influence of gender on academic performance and industrial relevance. The responses can be found at the end of this manuscript.

The responses show that gender does not influence academic performance, it is rather a matter of individual choices, parental upbringing, and commitment to one's academic pursuit. Also, class of degrees play a major role in employment opportunities. However, performance at work is a matter of how equipped an individual is and not necessarily your class of degrees. This finding coincides with the findings of [33], that attitudes rather than gender are what affects academic performance. Also, the above excerpts reveal that class of degrees plays some pivotal role in their employments while other respondents said the class of degrees does not really matter as there are many first class graduates still roaming the streets while their second class lower and third class counterparts already found something doing. This show some level of abnormality in the Nigerian system that plays little or no value on merit.

\section{Conclusion}

All social interactions and institutions are gendered in some manner. The consequence of the unequal division of labor may affect the zeal for competence among the females in society. Gender and development programs and policies must therefore be geared towards women empowerment and not just mere inclusion.

Although women are advancing in education, they still face many challenges in the industry. The major challenge is that female graduate do not translate their academic prowess into paid employment by securing job in the industry so as to demonstrate their capacity just as their male counterparts. Many of them however end up in marriage or even engage in the informal sector of the economy. The study concludes on the need for a level playing ground for both female and male students to maximize their potentials in today's world of work and while female students may be academically inclined, this achievement does not always correlate with their quest for career advancement in the labor market. On the other hand, male students who tend to be passive in their academics channel their energy in the workplace with better coping capacity and achievement.

\subsection{Recommendations}

The apparent disparities (as shown in table 4 above) in accessing social, economic, and political offices make women among the poorest and disadvantaged persons in society, especially in developing countries. Women are subjected to structural discrimination in the political and economic systems. Women carry double responsibility both as producers and also as agents of reproduction [32].

Nigeria as a nation is gifted with rich material and natural resources. Therefore, women mpowerment as a social organization is pertinent, and poverty must be addressed by creating opportunities for wealth and incomes, it is by so doing that sustainable development can be achieved [34]. 
[25] posits that the industries' activities can be enhanced by learning on the job as men. For instance, [11] asserts that both men and women bring their inherited socially determines roles, and these must not be overlooked for the organization to get the best from their various staffs.

It is generally acknowledged that economic development is closely linked to women's advancement. The 1994 World Survey on women's role in developing states emphatically state that women's advancement brings about steady economic growth and women subordination leads to economic stagnation.

According to [35], internationally, women's rights in Nigeria are guaranteed by the Africa Charter of Human and People's Rights and the Convention on the Elimination of all forms of discrimination.

The Nigerian woman, therefore, by the provision, has the right to the following;

i. To equal opportunities in employment, including the same criteria in selection.

ii. Not to be terminated from the job on the grounds of pregnancy.

iii. To credit facilities such as bank loans, mortgages, and other forms of financial credit.

iv. To equal education of the girl child/boy child.

Given the above, according to Aina (2012), female graduates must go through certain reorientation stated below:

i. Self-esteem and personal integrity are her values

ii. She becomes very proactive and assertive.

iii. She has made preparation for the challenges ahead, which could be education, wages, work-life and political participation. iv. She embraces motherhood's responsibility and is well equipped to challenge the world around her as she makes the demand for a social network of supports to balance her multiple gender roles.

\section{References}

[1] Onwumah, A. C., George, T. O., Olonade, O. Y., \& Adetunde, C. O. Factors Militating Against Gender Mainstreaming in Nigeria. Gender \& Behaviour, 17 (4), December 2019. 14038 - 14045 Copyright 2019 (C) Ife Centre for Psychological Studies/Services, Nigeria ISSN: $1596-9231$

[2] Fagbohun, George, Onwumah, Olonade, and Aderoju. Socio-cultural factors influencing Gender Differences in ICT adoption in Public Secondary Schools in Ogun State, Nigeria. Proceedings of EDULEARN18 Conference 2nd 4th July 2018, At: Palma Mallorca Spain.

[3] Lawanson, T. O. Gender Differentials in Nigeria: Implications for Sustainable Urban Development. Department of Urban and Regional Planning, University of Lagos, Akoka. 2008

[4] Azu, D., Egharevba, M. D. \& Azuh, A. E. Gender Discrimination and National Politics: The Nigerian Case. Covenant University Journal of Politics and International Affairs (CUJPIA). 2014. Vol. 2, No. 2.

[5] George, Fagbohun, Olonade and Aderoju. Rethinking Women's access to Education: A panacea for Sustainable Development in Nigeria. Proceedings of EDULEARN18 Conference 2nd - 4th July 2018, At: Palma Mallorca Spain.

[6] Jegede, A. S. African Culture and Health. Ibadan: Book Wright Publishers. 2016.

[7] Iwelumor, O. S., Shariffah, S. S. J., George, T. O., Babatunde, S. K., and Olonade, O. Y. "A Child is as important as Life": Reflections on the Value of Children from Infertile Couples. Open Access Macedonian Journal of Medical Sciences. 2020 Apr 20;8(E):302-307. https://doi.org/10.3889/oamjms.2020.3752

[8] Marc J. \& Judith M. Exploring gender differences in achievement through student voice: Critical insights and analyses, Cogent Education, 6:1, DOI: 10.1080/2331186 X. 2019.1567895 .

[9] Mankumari P. \& Ajay T. Gender Differences in the Academic Performance of Students. Journal of Development and Social Engineering Volume 3 | Number 1 | 2017, 39-47. ISSN 2382-5332 C) School of Development and Social Engineering, Pokhara University.

[10] Imogie, A.O. Overcoming Hurdles of Stereotypes about Sex and Leadership (Ed.). Benin Journal of Gender Studies, 1(2). Benin: JoeSeg Associates. 2009. 
[11] Aina, O. I. Two Halves make a Whole: Gender at the Crossroads of the Nigerian Development Agenda. Ile-Ife: Obafemi Awolowo University Press Limited. 2012.

[12] Pekkarinen, T. "Gender differences in education". IZA Discussion Paper, no. 6390.http://ftp.iza.org/dp6390.pdf. Retrieved October 22, 2019. 2012

[13] George. T. O., Onwumah, A. C., Fagbohun, M., Adebayo, M. E., and Olonade O. Y. Gender Differences in ICT Studies: A Study of Selected Public Secondary Schools in Ogun State, Nigeria. Gender Gaps and The Social Inclusion Movement in ICT. Eds by Idongesit Williams Aalborg, Olaga Millward Aalborg and Roslyn Layton. Published in the IGI Global book series Advances in Human and Social Aspects of Technology (AHSAT) (ISSN:2328-1316; Eissn:2328-1324). chapter 8, pp 147169.

[14] Okunnamiri, P. O. \& Okunnamiri, M. C. Equal opportunities and employment in Nigeria. Journal of Gender Studies, 1(4). Owerri: Centre for Women and Gender Studies. 2009

[15] Zuzana B. \& Thierry K. Gender disparities in employment and earnings in Sub-Saharan Africa: Evidence from Swaziland. IZA. 2016

[16] Madumere-Obike, C. U. "Women in management/administrative positions in rivers state secondary school sector". Journal of International Gender Studies (JIGS). University of Port Harcourt. 2004.

[17] Okwori, R. O. Gender inequality in education: the case of female and technology education. Journal of International Gender Studies (JIGS). University of Port Harcourt. 2004

[18] Ojo, J. O. and Abdulazeez, M. O. Women and their Technological Involvement in the Next Millennium: Women for Active Participation in the Next Millennium. Awka: Educational Research and Publishers. 1999.

[19] Elena M., Belinda A. \& Walter H. (2019). The gender gap in STEM fields: The impact of the gender stereotype of math and science on secondary students' career aspirations. Frontiers in Education 4, 60 .

[20] Olonade, O. Y., Busari, D. A., Imhonopi, D., George, T. O. and Adetunde, C. O. Gender-Based Perception and Lifestyle of Megamall Patrons in Ibadan, Nigeria. Proceedings of the 36th IBIMA Conference: 4-5 November 2020, Granada, Spain.

[21] Nwobodo, I. B. (2010). Gender Issues and Leadership Effectiveness in Nigeria Labour Union Activities: An Appraisal.

www.ilo.org/public/english/iira/documents/.../genderleadership.pdf.Retrieved October 22, 2013.

[22] Joekes, S. Trade-related Employment for Women in Industry and Services in Developing Countries. Geneva:
United Nations Research Institute for Social Development 1995.

[23] Adeleke, J., Olonade, O., Olaniyi, A., and George, T. Global Production, Consumerism, Supply Chain, and Rural Economy in Africa. The United Nations and Sustainable Development Goals. Eds by Folarin, S. F., Akinlabi, E. T., and Atayero, A. Published in the Palgrave Macmillan (in press).

[24] British Council Nigeria (2012). Gender in Nigeria Report 2012: Improving the Lives of Girls and Women in Nigeria. UKAID: UK Department for International Development.

[25] Amali, E. Gendernomics: Of Women, Work, and Economics. Department of Economics, University of Ilorin. http://www.unilorin.edu.ng/inaugural

lectures/gendernomics-women.pdf. 2007. Retrieved November 15, 2019

[26] Egbue, N. G. "Gender-based division of labour and women's avoidance of technical occupations in Nigeria" (Ed.). Journal of Sociology. Enugu: OKTEK Nigeria Limited. 2000.

[27] Adeboye, M. \& Mark, H. Gender pay gap in salary bands among employees in the formal sector of South Africa. SA Journal of Human Resource Management 16 (1), 1-10, 2018.

[28] Ighodalo, F. "Contributions of women to national development". Paper presented at the National Association of University Women to National Development. 1990.

[29] Ayodele, B. O. "Gender equality: An overview of the crises and contradictions in feminine empowerment". Journal of International Gender Studies (JIGS). University of Port Harcourt. 2004.

[30] Firestone, S. The Dialectic of Sex. London: Paladin. 1972.

[31] Omadjohwoefe, O. S. "Gender Role Differentiation and Social Mobility of Women in Nigeria". Journal of Social Science, 27(1). Department of Sociology \& Psychology. Delta State University, Abraka Nigeria. 2011.

[32] Oyelaran-Oyeyinka B. \& Adeyinka, F. "Technology and women in Nigeria". In Sesay, A. and Odebiyi, A. (Eds.). Nigerian Women in Society and Development. Ibadan: Dokun Publishing House. 1998.

[33] Olonade, O., Balogun, I., George, T., Adetunde, C., Ozoya, M., Adebayo, M. Academic Performance and Secondary School Students' Disposition: Imperatives for Sustainable Development Solutions for Africa We Want. The United Nations and Sustainable Development Goals. Eds by Folarin, S. F., Akinlabi, E. T., and Atayero, A. Published in Palgrave Macmillan (in press). 
[34] Kesselman, A., McNair, L. D. \& Schniedewind, N. Women, Images and Realities ( $4^{\text {th }}$ Ed.). Boston: McGraw Hill. 2013.

[35] Fapohunda, T. M. "Women and the informal sector in Nigeria: Implications for development". British Journal of Arts and Social Sciences, 4(1). British Journal Publishing, Inc. http://www.bjournal.co.uk/BJASS.aspx2012Retrieved November 15, 2019.

\section{Acknowledgment}

The authors appreciate Covenant University

through the Centre for Research Innovation

and Discovery for their immense support

\section{APPENDIX}

I think that gender does not exactly make a difference in academic performance, it all depends on one's commitment. In respect to extracurricular activities, in $C U$, girls perform better because the male is mostly found on the field playing football and basketball, girls are mostly in their room or library reading or engaging in academic work. In Nigeria, the class of degree does not have much relevance on industry relevance, first-class are found searching for jobs, and Other lower classes of degrees get jobs faster. Unlike other countries where your class of degree and hard work pays off. (100 Level Female Student, CDS).

In my University, guys have more distractions that keep them occupied, but I feel your personality makes a difference. If you want to be serious, you will; I feel it is how your parents raised you. Some boys do not even play balls or games; at the end of the day, it is not just your grades that determine industry relevance. Some first-class students are put on jobs and cannot perform. It is what you can do, not your grade. Gender does not matter. The past valedictorian for the last four years has more males than female students. (400 Level Male Student, CST).

Responses from selected graduates of the University revealed thus: and payment for the publication fee of this

manuscript.

\section{Author Contributions:}

Tayo George and Olanipekun Temilorun

prepared the manuscript

Mofoluwake Ajayi proofread and edited

Mercy Adebayo and Olawale Olonade update

the references and format the manuscript in

line with the journal guidelines

Gender makes a difference in academic performance. During my year in school, we had female students doing better than the male. Most males generally have less interest in academics, and females are more severe in having a stand in the patriarchal society. Class of degree is essential in employability in some firms these days. My class of degree has paved the ways for me (2013 female Graduate, College of Business and Social Sciences (CBSS), 2018)

Depending on the context, for sciences, I think the male performs better, and the female performs better for the social sciences. Generally, one's attitudes towards a thing determine the result he/she gets. These days, Industry relevance is dependent on what new thing you are willing to bring to the table. Organizations are searching for people who can deliver and have the zeal that yields productivity and not the class of degree or gender (2011 Female Graduates, College of Engineering, 2018)

From my point of view, female students are academically better than male. But it also depends on the subject and the lecturer style of teaching. Class of degree is not useful to me because so many people who did not go through school are excelling these days, while the first-class students are made to work them... (2013 Female Graduate CBSS, 2018)

\section{Creative Commons Attribution License 4.0 (Attribution 4.0 International, CC BY 4.0)}

This article is published under the terms of the Creative Commons Attribution License 4.0 https://creativecommons.org/licenses/by/4.0/deed.en US 